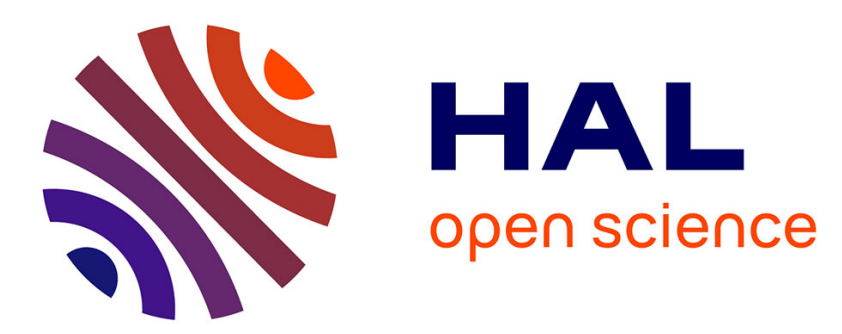

\title{
Susceptibility of the small hive beetle, Aethina tumida (Coleoptera: Nitidulidae), to insecticides and insect growth regulators
}

\author{
Lambert Kanga, Abisoye Somorin
}

\section{To cite this version:}

Lambert Kanga, Abisoye Somorin. Susceptibility of the small hive beetle, Aethina tumida (Coleoptera: Nitidulidae), to insecticides and insect growth regulators. Apidologie, 2011, 43 (1), pp.95-102. 10.1007/s13592-011-0101-1. hal-01003524

\section{HAL Id: hal-01003524 \\ https://hal.science/hal-01003524}

Submitted on 1 Jan 2011

HAL is a multi-disciplinary open access archive for the deposit and dissemination of scientific research documents, whether they are published or not. The documents may come from teaching and research institutions in France or abroad, or from public or private research centers.
L'archive ouverte pluridisciplinaire HAL, est destinée au dépôt et à la diffusion de documents scientifiques de niveau recherche, publiés ou non, émanant des établissements d'enseignement et de recherche français ou étrangers, des laboratoires publics ou privés. 


\title{
Susceptibility of the small hive beetle, Aethina tumida (Coleoptera: Nitidulidae), to insecticides and insect growth regulators
}

\author{
Lambert H. B. Kanga, Abisoye B. Somorin \\ Entomology Department/CESTA, Florida A\&M University, 406 Perry-Paige Bldg., Tallahassee, FL 32307, USA
}

Received 7 June 2010 - Revised 14 April 2011 - Accepted 5 July 2011

\begin{abstract}
The small hive beetle, Aethina tumida Murray, has become an important pest of the honeybee, Apis mellifera L., in the USA. In this study, we assessed the susceptibility of this pest to 14 selected insecticides and four insect growth regulators (IGRs). The results indicated that the small hive beetle (SHB) was selectively susceptible to several classes of insecticides. The lethal concentration for $50 \%$ mortality $\left(\mathrm{LC}_{50}\right)$ to adult SHBs was $0.53,0.53$, and $0.54 \mu \mathrm{g} /$ vial for fenitrothion, chlorpyrifos, and methomyl, respectively. However, against the larval stage, fenitrothion was the most toxic with an $\mathrm{LC}_{50}$ of $0.89 \mu \mathrm{g} / \mathrm{vial}$. Chlorpyrifos had an $\mathrm{LC}_{50}$ of $1.64 \mu \mathrm{g} / \mathrm{vial}$ which was similar to the $\mathrm{LC}_{50}$ of $1.21 \mu \mathrm{g} / \mathrm{vial}$ for fluvalinate and $2.24 \mu \mathrm{g} / \mathrm{vial}$ for methomyl. Overall, these insecticides were found to be more toxic to SHBs than the organophosphate coumaphos which is currently used for control of SHB populations. Among the IGRs tested, fenoxycarb and methoprene were the most effective on early instar larvae with an $\mathrm{LC}_{50}$ of 30.20 and $61.89 \mu \mathrm{g} / \mathrm{vial}$, respectively. None of the IGRs were found to adversely affect the development of third-fourth instar larvae of the SHB. The susceptibility of the SHB was also assessed in soil bioassays, and the patterns of responses were similar to those reported with the glass-vial bioassays. Our data provided useful insights and baseline in the development of an effective pest management strategy for the SHB in honeybee colonies. However, these pesticides should be used in a way that minimizes honeybee exposure and meets safety requirements for human consumption of honey products.
\end{abstract}

small hive beetle / honeybee / insecticides / insect growth regulators

\section{INTRODUCTION}

The honey bee, Apis mellifera L., is of great economic importance not only for honey production but also for crop pollination (Robinson et al. 1989). The added value of crops in the USA pollinated by honeybee was estimated at $\$ 14.6$ billion annually (Morse and Calderone

Corresponding author: L.H.B. Kanga,

lambert.kanga@famu.edu

Manuscript editor: Yves Le Conte
2000; Klein et al. 2007). Honeybee populations have significantly decreased over the past years due to various arthropod pests and pathogens (Ambrose et al. 2000; Ellis et al. 2010; Di Prisco et al. 2011). The most serious pests include the Varroa mite (Varroa destructor Anderson and Trueman), the tracheal mite (Acarapis woodi Rennie), and the small hive beetle (SHB) (Aethina tumida Murray). The SHB is native to sub-Saharan Africa, and entered the USA through Florida in 1998. It has since spread into more than 30 other states 
(Elzen et al. 1999a). The environmental requirements needed for a complete life cycle and survival of the SHB are easily met within the wide geographical distribution of the European honeybee, A. mellifera (Brown et al. 2002). The rapid spread and high reproductive potential of this pest, both within honeybee colonies and in stored products, coupled with the ability to overwinter in honeybee clusters make it a serious threat to apiculture (Elzen and Neumann 2004). Damage to the honeybee colonies is caused mainly by the feeding of larvae of the SHB on honey, pollen, and live broods. They also tunnel and pierce wax combs and defecate in stored honey causing it to ferment, weep, and froth away from the cells (Sanford 1999). As a result, the SHB represents a serious threat to honeybee colonies in Southern USA (Ellis and Hepburn 2006). The SHB was also reported to be a potential vector of honeybee viruses (Eyer et al. 2009).

The current chemical control methods for the SHB include the use of plastic strips of the organophosphorus insecticide, coumaphos $\left(\right.$ CheckMite $\left.^{\mathbb{B}}\right)$, under pieces of cardboard against adult SHB populations (Ellis and Delaplane 2007). Chemical treatments with coumaphos might leave residues in the honey products, were harmful to the bees, and failed to provide extended control of the pest (Elzen et al. 1999b; Hood 2000). In addition, a soil drench under infested colonies with permethrin (GardStar 40\% EC) has not been effective because it controls only few beetle larvae unless application is correctly timed (Schmolke 1974; Hood 2000). Several trapping devices were also developed for control of the SHB. These include the Hood beetle trap, the Freeman beetle trap, and the West beetle trap among others. All these traps typically use an attractant (often apple cider vinegar) and a killing agent (mineral oil); they are not stand-alone control measures of the SHB but provide some level of reduction of the SHB populations (Hood 2004). In this paper, we widen the search for compounds which might be effective against the larvae (during wandering phase prior pupation) and adults and thus might be useful in the development of an integrated pest management strategy for the SHB.

\section{MATERIALS AND METHODS}

\subsection{Insect collection}

Multiple field collections of adult SHBs from infested hives were made from the apiary at FAMU Research and Cooperative Extension Center, Quincy, FL and from Rish Tupelo Apiary, Wewahitchka, FL. They were brought to the laboratory, watered, and fed with a honey-fortified artificial diet and pollen substitutes (Global Patties, Butte, MT).

\subsection{Chemicals}

All insecticides and insect growth regulators were technical-grade samples ( $>90 \%$ purity) used as supplied by the manufacturers. The insecticides included the organophosphates fenitrothion, chlorpyrifos, malathion, parathion, phosmet, diazinon, metamidophos, and coumaphos (Chemical Service, West Chester, PA), the carbamates baygon, oxamyl, and methomyl (Chemical Service, West Chester, PA), the pyrethroids fluvalinate and cypermethrin (FMC, Princeton, NJ), and the organochlorine endosulphan (FMC, Philadelphia, PA). The insect growth regulators screened included tebufenozide, methoprene, cyromazin, and fenoxycarb (SigmaAldrich, Saint Louis, MO).

\subsection{Glass-vial bioassays}

The procedure used in this bioassay was described by Kanga and Plapp (1995). In this procedure, 20-mL glass scintillation vials were treated with $0.5 \mathrm{~mL}$ solution of each of the test insecticides or IGRs in acetone. Concentrations of $1.0 \times 10^{4}, 1.0 \times 10^{5}, 1.0 \times$ $10^{6}, 1.0 \times 10^{7}, 1.0 \times 0^{8} \mu \mathrm{g}$ per vial for insecticides and $1.0 \times 10^{2}, 1.0 \times 10^{3}, 1.0 \times 10^{4}, 1.0 \times 10^{5}, 1.0 \times 10^{6} \mu \mathrm{g}$ per vial for IGRs were tested. All insecticides or IGRs were diluted in acetone to get the desired concentrations for bioassays. The vials were rolled until the acetone evaporated and the insecticides were coated on the inner surfaces. Vials treated with acetone only were used as controls. Three last instar 
larvae or two adults were treated at each dose of the insecticides at room temperature $\left(25^{\circ} \mathrm{C}\right)$, and mortality was determined $24 \mathrm{~h}$ after exposure. The treatments were replicated ten times, and about 210 adults or larvae of the SHB were tested per insecticide and IGR. Adults or larvae that were unable to walk a short distance (up to $10 \mathrm{~mm}$ ) when released were considered dead.

\subsection{Soil bioassay}

Samples of oven-sterilized $\left(160^{\circ} \mathrm{C}, 1 \mathrm{~h}\right)$ soil $(20 \mathrm{~g})$ were placed inside plastic cups $(3.0 \times 1.5 \mathrm{~cm})$. The soil was humidified by sprinkling $2 \mathrm{~mL}$ of distilled water and allowed to settle for 30 min under a fume hood. A dilution ratio $(v / v)$ from $1: 1$ to $1: 10^{6}$ was tested for each insecticide and IGR in acetone. All chemicals were diluted in acetone to get the desired concentrations for bioassays, and the same amount of acetone without chemicals was used for controls. One milliliter of each concentration of the chemical was pipetted into the cups. Soil samples treated with acetone only were used as controls. Four last instar larvae of the SHB were placed in the cups, covered with a perforated lid, and held in a Percival Scientific Incubator $\left(27 \pm 1^{\circ} \mathrm{C}, 85 \% \mathrm{RH}\right.$, and 13:11-h L/D photoperiod) in the laboratory. There were four replicates per treatment, and the experiments were repeated on three different dates. About 192 insects were tested per experiment. Mortality of larvae of the SHB was recorded at 4, 7, and 14 days posttreatments.

\subsection{Statistical analyses}

The concentration-mortality data were subjected to Probit analysis to obtain the lethal concentrations (Russell et al. 1977). The control mortality was never greater than $5 \%$, and data were corrected using Abbott's (1925) formula. Differences among insecticides were considered not significant if the $95 \%$ confidence limit of their toxicity ratio at the $\mathrm{LC}_{50}$ bracketed 1.0 (Robertson and Preisler 1992). Percentage mortality was also adjusted for control mortality (Abbott 1925), and data from each time group were subjected to Probit analysis (logistic transformation) to generate lethal time response (LT) (SAS Institute 1996). Toxicity values $\left(\mathrm{LC}_{50} \mathrm{~s}\right)$ of the insecticides were compared to those of coumaphos (currently recommended to beekeepers for control of the SHB).

\section{RESULTS}

\subsection{Effect of insecticides in glass-vial bioassays}

Toxicity data indicated that adults and larvae of the SHB were susceptible to all insecticides tested, and the toxicity varied significantly between developmental stages of the SHB (Table I). The organophosphorus insecticides fenitrothion and chlorpyrifos were the most toxic, while methamidophos was the least efficacious in killing the SHB. Chlorpyrifos, fenitrothion, and parathion were significantly more toxic [(based on the failure of the $95 \%$ confidence limit of their toxicity ratio at the $\mathrm{LC}_{50}$ to bracket 1.0 (Robertson and Preisler 1992)] to adult SHBs than coumaphos, the insecticide currently being used to control the SHB populations.

Fenitrothion and malathion had similar toxicity as coumaphos to SHB (Table I). Among the carbamate insecticides tested, only methomyl was more toxic to adult SHBs, and the response was statistically different from that of coumaphos (Table II). All the other carbamate insecticides tested were less toxic to larval SHBs than coumaphos.

The pyrethroids fluvalinate and cypermethrin were equally toxic to both developmental stages of the $\mathrm{SBH}$ as coumaphos (Table III). The cyclodiene, endosulfan, was less toxic to the SHB than coumaphos (Table III).

\subsection{Effect of insect growth regulator in glass-vial bioassays}

First instar larvae of the SHB were generally more susceptible to IGRs than later instar larvae (Table IV). They were 2.6-, 1.5-, 1.4-, and 4.3-fold more susceptible at the $\mathrm{LC}_{50}$ level for fenoxycarb, cyromazin, tebufenozide, and methoprene, respectively. Larvae of the SHB appeared to be more susceptible to fenoxycarb than to methoprene. 
Table I. Responses of adults and larvae of Aethina tumida to organophosphorus insecticides in the laboratory.

\begin{tabular}{lllllc}
\hline Insecticides & Life stage & $N^{\mathrm{a}}$ & Slope $\pm \mathrm{SE}$ & $\mathrm{LC}_{50} \mathrm{~b}^{\mathrm{b}}(95 \% \mathrm{CL})$ & Toxicity ratio $^{\mathrm{c}}(95 \% \mathrm{CL})$ \\
\hline Chlorpyrifos & Adults & 264 & $3.58 \pm 0.47$ & $0.53(0.29-0.88)$ & $3.03(1.65-5.12)$ \\
& Larvae & 264 & $1.57 \pm 0.16$ & $1.64(0.94-2.24)$ & $0.80(0.62-1.76)$ \\
Fenitrothion & Adults & 320 & $3.86 \pm 0.5$ & $0.53(0.45-0.62)$ & $3.03(1.85-5.52)$ \\
& Larvae & 384 & $1.79 \pm 0.15$ & $0.89(0.71-1.10)$ & $1.48(0.93-2.31)$ \\
Parathion & Adults & 264 & $2.46 \pm 0.28$ & $0.68(0.54-0.84)$ & $2.37(1.32-4.83)$ \\
\multirow{5}{*}{ Malathion } & Larvae & 231 & $2.75 \pm 0.31$ & $1.46(1.19-1.80)$ & $0.90(0.73-1.85)$ \\
\multirow{5}{*}{ Phosmet } & Adults & 280 & $2.59 \pm 0.20$ & $0.84(0.62-1.14)$ & $1.92(0.99-2.87)$ \\
& Larvae & 424 & $1.75 \pm 0.14$ & $1.05(0.63-1.71)$ & $1.26(0.68-2.05)$ \\
Coumaphos & Adults & 264 & $2.48 \pm 0.20$ & $0.88(0.67-1.17)$ & $1.83(0.97-3.20)$ \\
\multirow{5}{*}{ Diazinon } & Larvae & 264 & $1.46 \pm 0.10$ & $0.89(0.71-1.10)$ & $1.48(0.91-2.23)$ \\
& Adults & 304 & $1.98 \pm 0.19$ & $1.61(0.98-2.58)$ & - \\
\multirow{2}{*}{ Methamidophos } & Larvae & 264 & $1.73 \pm 0.18$ & $1.32(0.92-1.89)$ & - \\
& Adults & 231 & $2.68 \pm 0.30$ & $1.22(0.98-1.50)$ & $1.31(0.81-2.11)$ \\
& Larvae & 320 & $1.33 \pm 0.13$ & $1.49(0.92-2.44)$ & $0.88(0.69-1.82)$ \\
& Adults & 240 & $2.73 \pm 0.32$ & $1.62(1.30-2.02)$ & $0.99(0.83-1.93)$ \\
& Larvae & 297 & $2.17 \pm 0.23$ & $5.69(4.51-7.22)$ & $0.23(0.12-1.34)$ \\
\hline
\end{tabular}

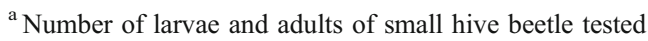

${ }^{\mathrm{b}}$ Concentrations are expressed in micrograms per vial of the insecticides tested

${ }^{\mathrm{c}}$ Toxicity ratios were calculated by dividing the $\mathrm{LC}_{50}$ for coumaphos by that of the other insecticides

Tebufenozide and cyromazin were equally toxic to first and fourth instar larvae of the SHB (Table IV).

\subsection{Effect of insecticides in soil bioassays}

Toxicity data indicated that SHB populations were susceptible to the insecticides tested using soil bioassays, and the mortality increased significantly over time (Table V). The toxicity of chlorpyrifos was significantly higher than that of fenitrothion. Further, chlorpyrifos was 2.48-fold and 6.97-fold more toxic than fenitrothion at 4 and 7 days posttreatment, respectively (Table V). The patterns of susceptibility of the SHB to chlorpyrifos and fenitrothion were similar to our previous results with the glass-vial bioassays.

Table II. Responses of adults and larvae of Aethina tumida to carbamate insecticides in the laboratory.

\begin{tabular}{lllllc}
\hline Insecticides & Life stage & $N^{\mathrm{a}}$ & Slope $\pm \mathrm{SE}$ & $\mathrm{LC}_{50}{ }^{\mathrm{b}}(95 \% \mathrm{CL})$ & Toxicity ratio $^{\mathrm{c}}(95 \% \mathrm{CL})$ \\
\hline \multirow{2}{*}{ Methomyl } & Adults & 264 & $2.81 \pm 0.34$ & $0.54(0.40-0.73)$ & $2.98(1.42-3.83)$ \\
& Larvae & 297 & $1.97 \pm 0.20$ & $2.24(1.76-2.87)$ & $0.59(0.41-1.52)$ \\
\multirow{2}{*}{ Propoxur } & Adults & 280 & $2.16 \pm 0.22$ & $1.74(1.24-2.41)$ & $0.92(0.78-1.87)$ \\
& Larvae & 336 & $1.84 \pm 0.17$ & $3.17(2.31-4.45)$ & $0.41(0.21-1.47)$ \\
\multirow{2}{*}{ Oxamyl } & Adults & 240 & $2.61 \pm 0.30$ & $1.96(1.31-2.91)$ & $0.84(0.63-1.73)$ \\
& Larvae & 264 & $1.46 \pm 0.15$ & $1.46(0.94-2.24)$ & $0.90(0.70-1.81)$ \\
\hline
\end{tabular}

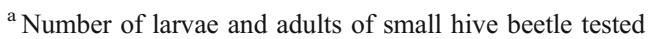

${ }^{\mathrm{b}}$ Concentrations are expressed in micrograms per vial of the insecticides tested

${ }^{\mathrm{c}}$ Toxicity ratios were calculated by dividing the $\mathrm{LC}_{50}$ for coumaphos by that of the other insecticides
} 
Table III. Responses of adults and larvae of Aethina tumida to pyrethroid and organoclorine insecticides in the laboratory.

\begin{tabular}{llllll}
\hline Insecticides & Life stage & $N^{\mathrm{a}}$ & Slope $\pm \mathrm{SE}$ & $\mathrm{LC}_{50}{ }^{\mathrm{b}}(95 \% \mathrm{CL})$ & Toxicity ratio $^{\mathrm{c}}(95 \% \mathrm{CL})$ \\
\hline Pyrethroids & & & & & \\
Cypermethrin & Adults & 320 & $1.85 \pm 0.17$ & $1.96(1.56-2.47)$ & $0.82(0.61-1.75)$ \\
& Larvae & 360 & $1.35 \pm 0.12$ & $1.91(0.98-4.04)$ & $0.69(0.52-1.68)$ \\
Fluvalinate & Adults & 280 & $2.29 \pm 0.34$ & $2.20(1.49-3.25)$ & $0.73(0.59-1.69)$ \\
& Larvae & 264 & $2.24 \pm 0.24$ & $1.21(0.96-1.52)$ & $1.09(0.65-1.98)$ \\
Cyclodiene & & & & & $0.19(0.10-1.29)$ \\
Endosulfan & Adults & 360 & $2.57 \pm 0.27$ & $8.70(7.17-10.61)$ & $0.21(0.13-1.32)$ \\
& Larvae & 297 & $1.91 \pm 0.20$ & $6.43(5.01-8.33)$ & \\
\hline
\end{tabular}

${ }^{a}$ Number of larvae and adults of small hive beetle tested

${ }^{\mathrm{b}}$ Concentrations are expressed in micrograms per vial of the insecticides tested

${ }^{\mathrm{c}}$ Toxicity ratios were calculated by dividing the $\mathrm{LC}_{50}$ for coumaphos by that of the other insecticides

\subsection{Effect of insect growth regulators in soil bioassays}

Data in Table VI indicated that fenoxycarb was more toxic to the larvae of the SHB and significantly different from cyromazin after days 4, 7, and 14. However, the levels of toxicity were lower until day 14, which may indicate the slow acting nature of these compounds. In addition, the lethal time for $90 \%$ mortality $\left(\mathrm{LT}_{90}\right)$ was 11.46 days for fenoxycarb and 15.37 days for cyromazin. Thus, it took more than 10 days for these compounds to kill $90 \%$ of the small hive beetle populations.

\section{DISCUSSION}

Results indicated that the SHB was selectively susceptible to several classes of insecticides and suggested potential new avenues for control. Among the eight organophosphorus insecticides tested, fenitrothion, chlorpyrifos, and parathion were more effective in controlling the SHB than was coumaphos, which is

Table IV. Responses of first and fourth instar larvae of Aethina tumida to insect growth regulators in the laboratory.

\begin{tabular}{llllcc}
\hline Insecticides & Life stage & $N^{\mathrm{a}}$ & Slope $\pm \mathrm{SE}$ & $\mathrm{LC}_{50}{ }^{\mathrm{b}}(95 \% \mathrm{CL})$ & Toxicity ratio $^{\mathrm{c}}(95 \% \mathrm{CL})$ \\
\hline Fenoxycarb & 1st instar & 105 & $2.24 \pm 0.39$ & $30.20(22.66-39.56)$ & $2.55(1.38-4.98)$ \\
& 4th instar & 160 & $2.09 \pm 0.27$ & $77.05(55.81-108.11)$ & - \\
Cyromazin & 1st instar & 105 & $2.11 \pm 0.35$ & $30.72(18.46-47.70)$ & $1.54(0.95-2.28)$ \\
& 4th instar & 160 & $1.50 \pm 0.19$ & $47.29(24.45-64.79)$ & - \\
Tebufenozide & 1st instar & 105 & $2.96 \pm 0.54$ & $25.94(19.19-34.29)$ & $1.45(0.87-2.12)$ \\
& 4th instar & 160 & $1.55 \pm 0.20$ & $37.52(24.84-46.90)$ & - \\
Methoprene & 1st instar & 105 & $2.31 \pm 0.38$ & $61.89(39.53-94.69)$ & $4.29(2.84-6.98)$ \\
& 4th instar & 160 & $1.89 \pm 0.28$ & $266.05(191.37-383.63)$ & - \\
\hline
\end{tabular}

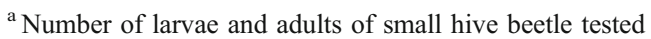

${ }^{\mathrm{b}}$ Concentrations are expressed in micrograms per vial of the insect growth regulators tested

${ }^{\mathrm{c}}$ Toxicity ratios were calculated by dividing the $\mathrm{LC}_{50}$ for 4 th instar by that of 1 st instar
} 
Table V. Responses of last instar larvae of Aethina tumida to chlorpyrifos and fenitrothion in soil bioassays.

\begin{tabular}{lllllc}
\hline Insecticides & Life stage & $N^{\mathrm{a}}$ & Slope $\pm \mathrm{SE}$ & $\mathrm{LC}_{50}{ }^{\mathrm{b}}(95 \% \mathrm{CL})$ & Toxicity ratio $^{\mathrm{c}}(95 \% \mathrm{CL})$ \\
\hline $\begin{array}{l}\text { After 4 days } \\
\text { Chlorpyrifos }\end{array}$ & Larvae & 300 & $5.01 \pm 0.69$ & $3.71(2.97-4.59)$ & $2.48(1.32-4.92)$ \\
$\begin{array}{l}\text { Fenitrothion } \\
\text { After 7 days }\end{array}$ & Larvae & 300 & $6.62 \pm 1.00$ & $9.20(7.61-11.18)$ & - \\
Chlorpyrifos & Larvae & 300 & $6.36 \pm 1.23$ & $0.73(0.57-0.89)$ & $6.97(3.42-13.63)$ \\
Fenitrothion & Larvae & 300 & $3.94 \pm 0.48$ & $5.09(4.00-6.50)$ & - \\
\hline
\end{tabular}

${ }^{a}$ Number of larvae and adults of small hive beetle tested

${ }^{\mathrm{b}}$ Concentrations are expressed in micrograms per cup of the insecticides tested

${ }^{\mathrm{c}}$ Toxicity ratios calculated by dividing the $\mathrm{LC}_{50}$ for fenitrothion by that of chlorpyrifos

currently used for in-hive treatments. The carbamate methomyl and the pyrethroids, cypermethrin and fluvalinate, might also be used to control the SHB populations. In similar studies using feeding bioassays, Ellis and Delaplane (2007) reported that fluvalinate was toxic to feeding and wandering larvae but innocuous to adults, while coumaphos had the broader toxicity, killing both larvae and adults. Thus, chlorpyrifos, fenitrothion, parathion, fluvalinate, cypermethrin, and methomyl might also be used judiciously as bait stations within the beehives for control of the SHB. In soil treatments, chlorpyrifos was more effective against late instar larvae than permethrin, which is currently used in soil drench applications. The last instar larvae appeared to be the most vulnerable stage as the larvae seek suitable soil sites for pupation and therefore more accessible to treatments. Because of the deleterious effects of pesticides, any compounds to be used in or around the beehive for control of the SHB are required to be less toxic to honeybee populations and meet safety requirements for human consumption of honey products. However, Hardstone and Scott (2010) indicated that in general, honeybees were no more sensitive than other insect species to the six classes of insecticides (carbamates,

Table VI. Responses of last instar larvae of Aethina tumida to fenoxycarb and cyromazin in soil bioassays.

\begin{tabular}{llcccc}
\hline Insecticides & Life stage & $N^{\mathrm{a}}$ & Slope $\pm \mathrm{SE}$ & $\mathrm{LC}_{50} \mathrm{~b}^{\mathrm{b}}(95 \% \mathrm{CL})$ & Toxicity ratio $^{\mathrm{c}}(95 \% \mathrm{CL})$ \\
\hline $\begin{array}{l}\text { After 4 days } \\
\text { Fenoxycarb }\end{array}$ & Larvae & 312 & $2.19 \pm 0.28$ & $356(241-497)$ & $5.36(3.05-11.02)$ \\
$\begin{array}{l}\text { Cyromazin } \\
\text { After 7 days }\end{array}$ & Larvae & 312 & $3.83 \pm 0.56$ & $1,910(1,532-2,382)$ & - \\
$\begin{array}{l}\text { Fenoxycarb } \\
\text { Cyromazin }\end{array}$ & Larvae & 312 & $2.13 \pm 0.32$ & $341(204-500)$ & $5.30(2.98-10.85)$ \\
After 14 days & & 312 & $4.67 \pm 0.64$ & $1,810(1,277-2,497)$ & - \\
$\begin{array}{l}\text { Fenoxycarb } \\
\text { Cyromazin }\end{array}$ & Larvae & 312 & $1.64 \pm 0.41$ & $40(4-102)$ & $7.93(5.41-14.35)$ \\
\hline
\end{tabular}

${ }^{\mathrm{a}}$ Number of larvae of small hive beetle tested

${ }^{\mathrm{b}}$ Concentrations are expressed in micrograms per cup of the insect growth regulators tested

${ }^{\mathrm{c}}$ Toxicity ratios calculated by dividing the $\mathrm{LC}_{50}$ for cyromazin by that of fenoxycarb 
nicotinoids, organochlorines, organophosphates, pyrethroids, and miscellaneous chemicals) they examined. The fact that fenitrothion, parathion, chlorpyrifos, and methomyl were more toxic than coumaphos to the SHB may suggest that lower concentrations of these chemicals could be used to achieve successful control measures, therefore reducing chemical usage and contamination of honey, honey products, and the environment.

The SHB is not restricted to honeybees and can reinvade hives from other sources; thus, a long-term management strategy is needed. Our data on insect growth regulators indicated that fenoxycarb and methoprene were more effective against early instar larvae than older larvae. Further, the toxicity of tebufenozide and cyromazin was similar between first and fourth instar larvae of the SHB. These chemicals could be used judiciously (sequential or rotational use) with other control measures to design an effective integrated pest management strategy. Because of the broad spectrum activity of the OP, carbamate, and pyrethroid insecticides and their adverse impacts on honeybees, there is merit of widening the search for alternatives to coumaphos. The search should include neonicotinoids, pyrazoles, pyroles, avermectins, and newer generations of insecticides. Hardstone and Scott (2010) indicated that while honeybees can be sensitive to individual insecticides, they were not a highly sensitive species to insecticides overall, or even to specific classes of insecticides. However, all pesticides should be used in a way that minimizes honeybee exposure.

Overall, this study provided useful insights and baseline data in the development of a costeffective pest management strategy for the small hive beetle in the honeybee industry. However, studies of the toxicity of these insecticides to honeybees are yet to be conducted.

\section{ACKNOWLEDGMENTS}

We thank Janice Peters (Florida A\&M University) and Carlos Gracia (USDA, ARS, Weslaco; TX) for their assistance with this study. We are grateful to
Susie Legaspi, Stuart Reitz (USDA-ARS, Tallahassee, FL), and Manuel Pescador (Florida A\&M University) for providing useful discussions and reviews of the manuscript. We also thank James Rish (Tupelo Honey) for his assistance in managing the honeybee colonies during the field trials.

Sensibilité du petit coléoptère des ruches, Aethina tumida (Coleoptera: Nitidulidae) envers les insecticides et les régulateurs de croissance d'insectes.

Abeille / ravageur / lutte / insecticide / régulateur de croissance / ennemi de la ruche

Anfälligkeit des kleinen Beutenkäfers Aethina tumida (Coleoptera: Nitidulidae) gegen Insektizide und Wachstumsregulatoren.

\section{kleiner Beutenkäfer / Honigbiene / Insektizide / Wachstumsregulatoren}

\section{REFERENCES}

Abbott, W.S. (1925) A method of comparing the effectiveness of insecticides. J. Econ. Entomol. 18, 265-267

Ambrose, J.T., Stanghellini, M.S., Hopkins, D.I. (2000) A scientific note on the threat of small hive beetles (Aethina tumida Murray) to bumble bees (Bombus sp.) colonies in the United States. Apidologie 31, 455-456

Brown, M.A., Thompson, H.M., Brew, M. (2002) Risks to UK beekeeping from the parasitic mite Tropilaelaps clareae and the small hive beetle, Aethina tumida. Bee World 83, 151-164

Di Prisco, G., Pennacchio, F., Caprio, E., Boncristiani Jr., H.F., Evans, J.D., Chen, Y. (2011) Varroa destructor is an effective vector of Israeli acute paralysis virus in the honey bee, Apis mellifera. J. Gen. Virol. 92, 151-155

Ellis, J.D., Hepburn, H.R. (2006) An ecological digest of the small hive beetle (Aethina tumida), a symbiont in honey bee colonies (Apis mellifera). Insects Sociaux 53, 8-19

Ellis, J.D., Delaplane, K.S. (2007) The effects of three acaricides on the developmental biology of small hive beetles (Aethina tumida). J. Apic. Res. and Bee World 46, 256-259

Ellis, J.D., Evans, J.D., Pettis, J. (2010) Colony losses, managed colony population decline, and Colony 
Collapse Disorder in the United States. J. Apic. Res. 49, 134-136

Elzen, P.J., Baxter, J.R., Westervelt, D., Randall, C., Cutts, L., Wilson, W., Eischen, F.A., Delaplane, K. S., Hopkins, D.I. (1999a) Status of the small hive beetle in the U.S. Bee Culture 127, 28-29

Elzen, P.J., Baxter, J.R., Westervelt, D., Randall, C., Cutts, L., Wilson, W.T. (1999b) Field control and biology studies of a new pest species, Aethina tumida Murray (Coleoptera: Nitidulidae) attacking European honey bees in the Western hemisphere. Apidologie 30, 361-366

Elzen, P.J., Neumann, P. (2004) The biology of the small hive beetle (Aethina tumida, Murray): Gaps in our knowledge of an invasive species. Apidologie 35, 229-247

Eyer, M., Chen, Y.P., Schäfer, M.O., Pettis, J., Neumann, P. (2009) Small hive beetle, Aethina tumida, as a potential biological vector of honeybee viruses. Apidologie 40, 419-428

Hardstone, M.C., Scott, J.G. (2010) Is Apis mellifera more sensitive to insecticides than other insects? Pest Manage Sci. 66, 1171-1180

Hood, W.M. (2000) Overview of the small hive beetle Aethina tumida in North America. Bee World 81, 129-137

Hood, W.M. (2004) The small hive beetle, Aethina tumida: A review. Bee World 85, 51-59

Kanga, L.H.B., Plapp Jr., F.W. (1995) Development of a technique to monitor resistance to biodegradable insecticides in field populations of tobacco budworm. J. Econ. Entomol. 88, 487-494

Klein, A.M., Vaissière, B.E., Cane, J.H., SteffanDewenter, I., Cunningham, S.A., Kremen, C., Tscharntke, T. (2007) Importance of pollinators in changing landscapes for world crops. Proc. R. Soc. B-Biol. Sci. 274, 303-313

Morse, R.A., Calderone, N.W. (2000) The value of honey bees as pollinators of US crops in 2000. Bee Cult. 128, 2-15

Robertson, J.L., Preisler, H.K. (1992) Pesticide bioassays with arthropods. CRC, Boca Raton

Robinson, G., Willard, S., Nowogrodski, R., Morse, R. A. (1989) The value of honey bees as pollinators of US crops. Am. Bee J. 129, 477-487

Russell, R.M., Robertson, J.L., Savin, N.E. (1977) POLO: a new computer program for Probit analysis. Bull. Entomol. Soc. Am. 23, 209-213

Sanford M.T. (1999) Small Hive Beetle (Aethina tumida). APIS: Apicultural Information and Issues, University of Florida, Cooperative Extension newsletter topics. EENY-094 (http://apis.ifas.ufl.edu/ threads/smbeetle.htm)

SAS Institute (1996) SAS/STAT Software. Changes and enhancements. SAS Institute, Cary

Schmolke M.D. (1974) A study of Aethina tumida: the small Hive Beetle, Project Report, University of Rhodesia, pp. 178 